\title{
Energy Equivalent of Rainwater Harvesting for High-Rise Building in the Philippines
}

\author{
Jibsam F. Andres ${ }^{1,2^{*}}$, Michael E. Loretero ${ }^{1,3}$ \\ ${ }^{1}$ Engineering Graduate Study, University of San Carlos, Talamban Campus, Cebu City, Philippines \\ ${ }^{2}$ College of Engineering and Technology, Western Philippines University, Aborlan, Palawan, Philippines \\ ${ }^{3}$ Department of Mechanical and Manufacturing Engineering, University of San Carlos, Talamban Campus, Cebu City, Philippines
}

Received November 12, 2020; Revised December 25, 2020; Accepted January 20, 2021

\section{Cite This Paper in the following Citation Styles}

(a): [1] Jibsam F. Andres, Michael E. Loretero, "Energy Equivalent of Rainwater Harvesting for High-Rise Building in the Philippines," Civil Engineering and Architecture, Vol. 9, No. 1, pp. 74 - 84, 2021. DOI: 10.13189/cea.2021.090106.

(b): Jibsam F. Andres, Michael E. Loretero (2021). Energy Equivalent of Rainwater Harvesting for High-Rise Building in the Philippines. Civil Engineering and Architecture, 9(1), 74 - 84. DOI: 10.13189/cea.2021.090106.

Copyright@2021 by authors, all rights reserved. Authors agree that this article remains permanently open access under the terms of the Creative Commons Attribution License 4.0 International License

\begin{abstract}
The Philippines is in a tropical location where rainwater is abundant for the frequent rain in a year. Rainwater becomes waste flowing down the drains causing flood, especially in urban areas. This problem initiates local governments in some cities in the Philippines to adapt and implement Green programs that require the installation and utilization of rainwater catchment system. Though this program addresses the control of flood caused by the rain, the generation of energy by utilizing rainwater as an energy source is not yet considered. With this, the study computes the equivalent energy generation by utilizing rainwater. The rainwater energy equivalent includes the following: the increasing number of high-rise building construction as catchment facility; the rainfall precipitation of 58 stations in the Philippines; the floor area and the types of the building; and the volume of water consumption per person per day. The energy equivalent was computed using the $40 \%$ of the time the rainfall precipitation equaled or exceeded the other with the average floor area specified from the approved building permit as of 2017. The study established a mathematical equation as an equivalent energy of rainwater utilization. The equation of energy equivalent was derived using the initial building height of 5 meters and an additional succeeding height of 3 meters per floor level.
\end{abstract}

Keywords Rainwater, Rainfall Precipitation, Energy, High-Rise Buildings

\section{Introduction}

Heavy rainwater precipitation, which in other contexts is welcomed because it provides and supplies the necessary water for agricultural purposes and even for domestic use. On the other hand, heavy rainwater precipitation may also cause deadly and destructive flash floods. The presence of rainfall exists in many locations and is considered an abundant source of water. Though it might have a negative impact in a few aspects, the utilization of this water resource was studied in terms of rainwater harvesting system abbreviated as RWH or RHS. Studies on rainwater harvesting were considered sustaining shortage of water supplies for irrigation, washing purposes as well as potable water. Rainwater harvesting is an indigenous resources considered as a source of renewable energy. This implies that this RWH contributes importance for sustainable development since it has zero environmental impact compared to conventional energy [1].

The study on hybrid system, solar-wind-rain eco-roof system also includes and mix Rainwater harvesting [2]. Rainwater in this study is collected in the tanks purposely for the efficient use of energy in which the collected rainwater will be used to spray the roof to maintain cooling in the building. Another tank in the design system was used for washing purposes. Rainwater harvesting technique was significantly studied as a supply of water needed mostly for non-potable water application followed by rainwater treatment for potable or drinking water purposes. 
Previous studies on RWH don't include the possible generation of energy when stored rainwater is utilized. If rainwater is collected, the utilization of it for any purpose could be a source of energy. This is by collecting and storing the rainwater at a certain height of the building or at the same height of the existing building. When stored rainwater is utilizing, the gravitational flow of water could be the generation of energy. This may be established by using small-scale hydro-turbine such as tesla turbine [3] or any hydro turbine for small water flow. The small amount of energy are then be multiplied by arranging turbine-generators in series or in parallel along the small-scale water resources. This small-scale generated energy could supply LED lights and rural electrifications. With these, the concept of the energy equivalent of rainwater was considering using mathematical computation. Factors that influenced this rainwater energy equivalent were the increasing number of building construction, the rainfall precipitation, roof area or floor area of the building, the height of the building, and the volume of water consumption.

\section{Materials and Methods}

\subsection{Runoff Coefficient}

Runoff coefficient $(\mathrm{Cr})$ is a factor on harvesting rainwater based from the roofing material used in buildings $[2,4,5]$. The runoff coefficient was assumed to be 0.80 for each day over the ten-year period. The water availability was computed from the precipitation over the existing drainage area (collection area) [4]. Another study assumed $\mathrm{Cr}$ to be 0.75 [6]. The use of the concept of runoff coefficient is common in the literature, but it is inaccurate since the proportion of rainwater retained is not independent on the total amount of each particular precipitation event [6]. While the use of $\mathrm{Cr}$ as 1.0 was considered in this study.

\subsection{Rainfall Precipitation and Duration Curve}

There were 58 location sites in the Philippines in which the monthly rainfall precipitation was observed [7]. The rainfall precipitation considered in this study was a 23-year rainfall data from 1990-2012 [7]. Computations used the Microsoft Excel that determines the rainfall precipitation duration curve (RPDC) of each station [8]. Rainfall precipitation was evaluated and computed into rainfall precipitation curve, which determined the rainfall precipitation percentage of time equaled or exceeded. The study considered the $40 \%$ of the time of the rainfall precipitation curve in the computation of equivalent energy generation of rainfall harvesting system.

Method of RPDC is the same as flow duration curve when river flow was considered to be a source of energy
[8]. It is by taking all the rainfall precipitation records over the year and placing them with the highest figures on the left and the lower figure placed progressively over to the right.

\subsection{Catchment Area}

The catchment area that determines the equivalent energy of rainwater harvesting was the floor area of different types of approved buildings in the Philippines as of the first quarter of year 2017 [7]. Data were an open source from the website of Philippine Statistic Authority (PSA) while the volume of water consumption per person per day per types of use was from the literature related to this study $[7,9,10,11]$.

Types of water consumption where the shower, washing machine, dish washing, toilet flushing, outside washing, kitchen tap and basin taps. Dwelling units were categorized as shown in Tables 1 and 2 below.

Table 1. Specific data of Column/Row

\begin{tabular}{|c|c|c|c|}
\hline \multicolumn{2}{|c|}{ Dwelling Unit [9] } & \multicolumn{2}{c|}{ Residential Building [7] } \\
\hline Type & Roof Area $\left.\mathbf{( m}^{2}\right)$ & Type & Floor Area $\mathbf{( m}^{2} \mathbf{~}$ \\
\hline 1 & 50 & Single & 105.25 \\
\hline 2 & 75 & Duplex & 163.46 \\
\hline 3 & 100 & Apartment & 264.19 \\
\hline 4 & 150 & Condo & $32,533.46$ \\
\hline 5 & 200 & Condo & 150.46 \\
\hline
\end{tabular}

Table 2. Specific data of Column/Row

\begin{tabular}{|c|c|c|c|}
\hline \multicolumn{2}{|c|}{ Dwelling Houses [10] } & \multicolumn{2}{c|}{ Dwelling Unit [11] } \\
\hline Type & Roof Area $\left(\mathrm{m}^{2}\right)$ & Type & Floor Area $\left(\mathrm{m}^{2}\right)$ \\
\hline Popular & 40 & 1 & 100 \\
\hline Low standard & 60 & 2 & 200 \\
\hline $\begin{array}{c}\text { Normal } \\
\text { standard }\end{array}$ & 110 & 3 & 300 \\
\hline High standard & 220 & $\mathrm{x}$ & $\mathrm{x}$ \\
\hline
\end{tabular}

Factors in assessing rainwater harvesting and utilization were the roof area or floor area of the building as well as the runoff coefficient, $\mathrm{Cr} \quad[4,5 \cdot 6,9,10,12]$. Study considered the single family houses having roof area ranges between $50-250 \mathrm{~m}^{2}$ and are divided into a roof area to $50,75,100,150$ and $250 \mathrm{~m}^{2}$ [9]. While the term "types of residential" were defined into four catchment areas which were as follows; $40 \mathrm{~m}^{2}$ for popular houses, 60 $\mathrm{m}^{2}$ for low-standard houses, $110 \mathrm{~m}^{2}$ for normal-standard houses and $220 \mathrm{~m}^{2}$ for high-standard houses [10].

The average floor area in the Philippines, has the average floor area of $105.25 \mathrm{~m}^{2}$ for single dwelling unit, $163.46 \mathrm{~m}^{2}$ for duplex/qoud, $267.19 \mathrm{~m}^{2}$ for an apartment, $32,522.24 \mathrm{~m}^{2}$ for a condo, and $150.46 \mathrm{~m}^{2}$ other than residential [6]. Floor area of non-residential building were; $533.78 \mathrm{~m}^{2}$ for commercial, $1720.49 \mathrm{~m}^{2}$ for industrial, 
$711.31 \mathrm{~m}^{2}$ for institutional and $800 \mathrm{~m}^{2}$ for agricultural and other non-residential buildings [7].

\subsection{Energy Equivalent of Rainwater}

The rainfall precipitation duration curve is a series computation that uses the statistical method. This method also used to determine not the average of the data, but the most conservative rainfall precipitation method used for the computation of energy equivalent. The rainfall precipitation at $40 \%$ of the rainfall precipitation duration curve were considered computing the potential rainwater energy equivalent. The potential energy of rainwater precipitation collected from the existing buildings was computed by the equations (1) and (2) $[5,14,15]$ as,

$$
\begin{gathered}
\mathrm{PE}=\delta \mathrm{gV}_{\mathrm{ol}} \mathrm{HCr} \\
\mathrm{V}_{\mathrm{ol}}=\mathrm{R}_{\mathrm{p}} \mathrm{R}_{\mathrm{a}}
\end{gathered}
$$

Where, PE is potential energy in Joules, $\mathrm{V}_{\mathrm{ol}}$ is volume of water in $\mathrm{m}^{3}$, g is gravity in $9.8 \mathrm{~m} / \mathrm{s}^{2}, \delta$ is water density equal to $1000 \mathrm{~kg} / \mathrm{m}^{3}, \mathrm{H}$ is head of water in a meter (m) and $\mathrm{Cr}$ as the runoff coefficient equal to 1 .

$R_{p}$ is the rainfall precipitation in mm (from duration curve) and $R_{a}$ is the roof area of the building in $\mathrm{m}^{2}$. Energy conversion from Joules to watt-hour is express by 1 watt-hour $=3600$ Joules $(\mathrm{J})$.

\subsection{Water Consumption Per Person Per Day}

The assumption on the volume of water varies with the type and purpose the water was used. The volume of water consumption per person per day, usually observed in houses was in the figures of 100,150, 200 and 250 liters (L) per day (d) per person (p) [9]. Consumption of domestic water demand for toilet flushing is $30 \mathrm{~L} / \mathrm{p} / \mathrm{d}$ and $25 \mathrm{~L} / \mathrm{p} / \mathrm{d}$ for showering [12]. The increasing amount of water consumption from $35 \mathrm{~L} / \mathrm{p} / \mathrm{d}$ to $45 \mathrm{~L} / \mathrm{p} / \mathrm{d}$ is the amount of wastewater discharge from the shower, while the water flushing toilets increased to $35 \mathrm{~L} / \mathrm{p} / \mathrm{d}$ or $40 \mathrm{~L} / \mathrm{p} / \mathrm{d}$. This implies an increasing demand of non-potable water [12].

The non-potable water consumption was used to determine the equivalent energy for domestic uses. The non-potable for showering has $60 \mathrm{~L} / \mathrm{p} / \mathrm{d}$ which is the highest contribution of $39 \%$ of the total domestic water consumption, toilet flushes of $45 \mathrm{~L} / \mathrm{p} / \mathrm{d}(29 \%)$, washing machine and kitchen tap of $12 \mathrm{~L} / \mathrm{p} / \mathrm{d}$ each (8 \% each), basin tap of $21 \mathrm{~L} / \mathrm{p} / \mathrm{d}$ (14\%) and dishwashing and outside washing as the smallest consumption of $2 \mathrm{~L} / \mathrm{p} / \mathrm{d}$ each $(1 \%$ each) of the total water consumption [4].

Water consumption for domestic use in a dwelling units is tabulated shown in Table 3 below [4]. Volume of water consumption is expressly in liters (L) for every person (p) dwelled in any types of residential buildings per day (d). The equivalent energy generation of domestic water consumption was computed based from the literature's volume of water consumed in each room location of dwelling units.

Table 3. Dwelling units water consumption

\begin{tabular}{|c|c|}
\hline Dwelling Unit locations & $\begin{array}{c}\text { Volume of water consumed } \\
\text { per person per day (L/p/d) }\end{array}$ \\
\hline Shower & 60 \\
\hline Toilet flushing & 45 \\
\hline Washing machine & 12 \\
\hline Kitchen tap & 12 \\
\hline Basin tap & 21 \\
\hline Kitchen tap & 12 \\
\hline Dishwashing & 2 \\
\hline Outside washing & 2 \\
\hline
\end{tabular}

\section{Results}

\subsection{Rainfall Precipitation in the Philippines}

There were 58 stations in the Philippines, which monthly precipitation observed [7]. Rainfall precipitation for the past 23 years (1990-2012) was converted into a rainfall precipitation duration curve per station. Figure 1 was the rainfall precipitation curve (RPC) of Hinatuan City which has the highest rain precipitation among the 58 stations in the Philippines. At $40 \%$ of time equaled or exceeded, the rainfall precipitation of Hinatuan City was $312.97 \mathrm{~mm}$. The rainfall precipitations at $40 \%$ were used to compute the energy equivalent of rainwater.

Figure 2 below shows the average rainfall precipitation and the $40 \%$ of time equaled or exceeded rainfall precipitation in each 58 station. Hinatuan, Surigao del Sur recorded the highest average rainfall precipitation of $403.52 \mathrm{~mm}$ while General Santos City recorded with the lowest precipitation. 


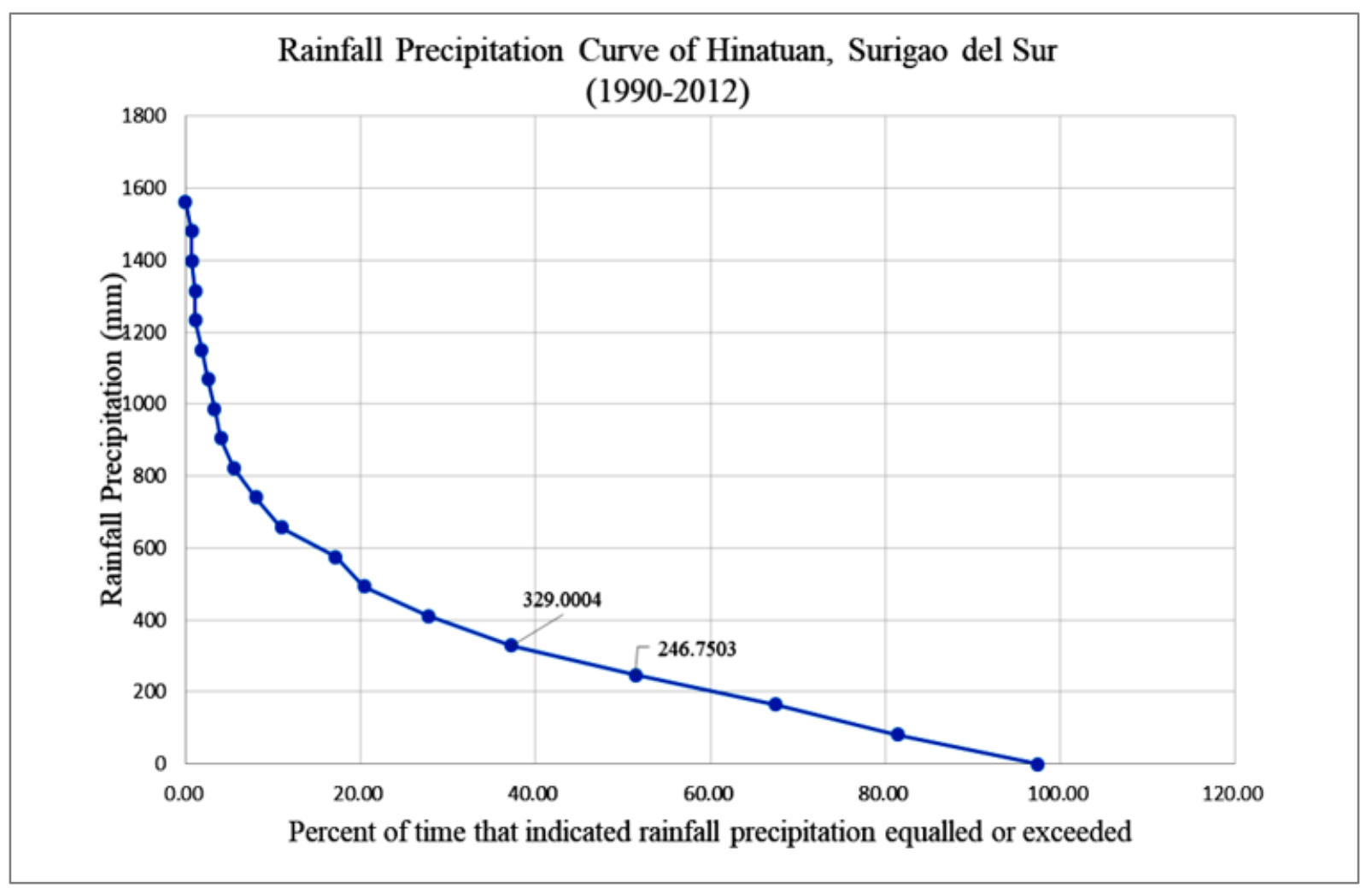

Figure 1. Sample Rainfall duration curve

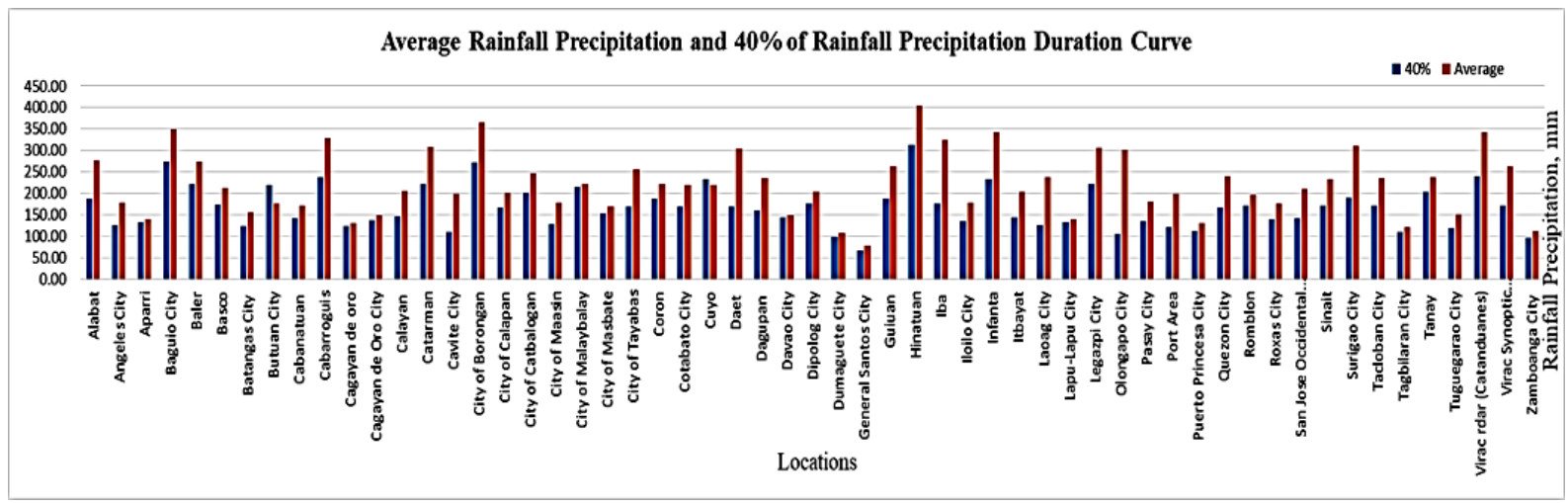

Figure 2. Rainfall precipitation of 58 locations in the Philippines

\subsection{Potential Energy of Rainwater from Residential and other Buildings}

Residential buildings are divided into four (7) types; such as the single dwelling unit, double/quodro, apartment, condo and other residential. The area used for the Condo units was $300 \mathrm{~m}^{2}$ [7]. Figure 4.3 below shows the rainwater potential energy equivalent of each type of residential building in the Philippine settings with an assumed height of five (5) meters applied to all types of building.

Figures 3 and 4 shows the potential energy equivalent for different category of residential buildings and different types of building constructions. The potential energy equivalent is computed only for the first 5 meter height of the building with a rainfall precipitation from Hinatuan City station. This implies a directly proportional energy generation increase as building constructed higher than the initial height considered. As shown in Figure 3, the first 5-meter height of the building has the highest equivalent energy of $1279.26 \mathrm{Whr}$ for apartment type of residential building and 2756.75 Whr for industrial buildings of non-dwelling units as shown in Figure 4 below. 


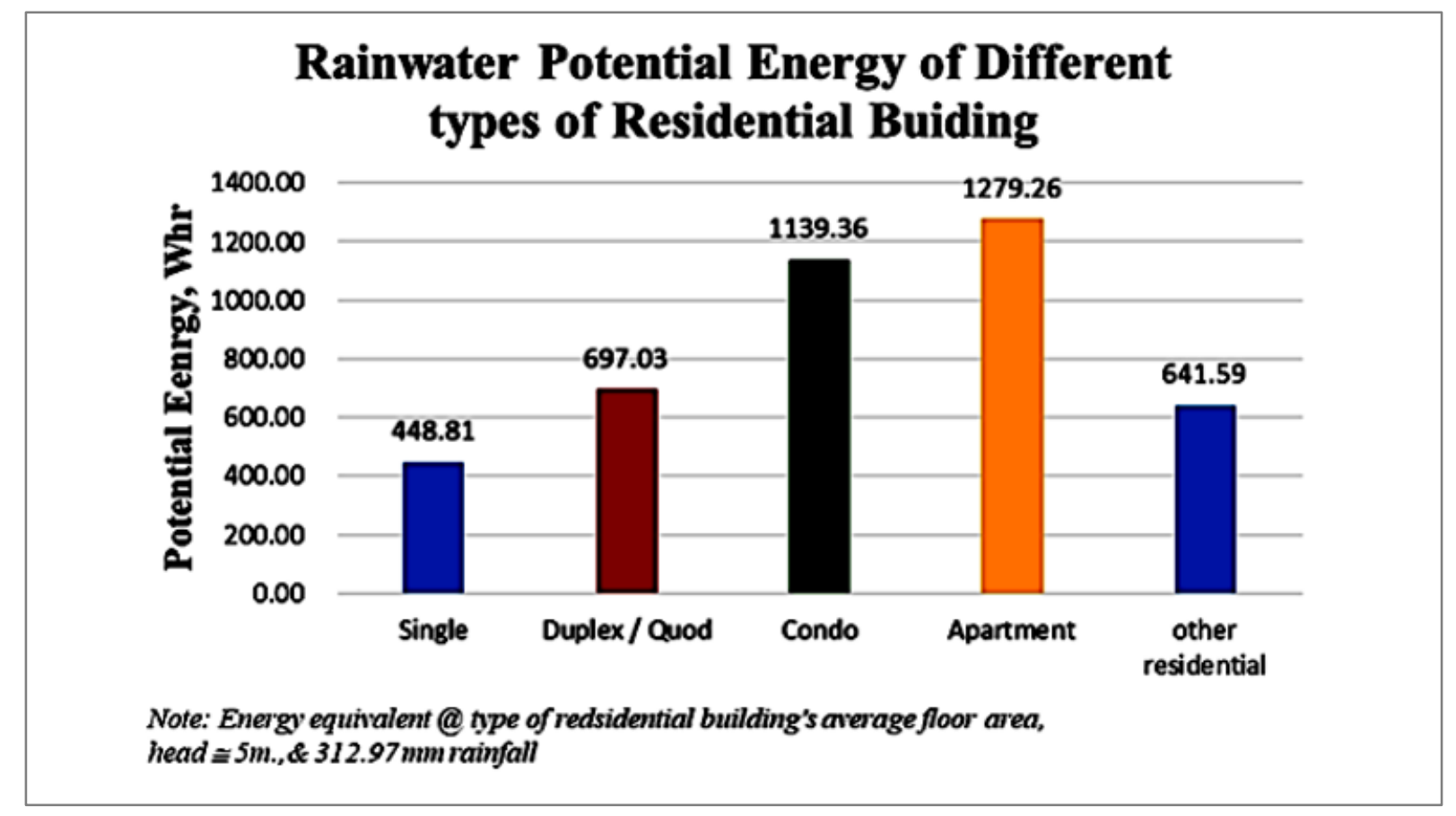

Figure 3. Potential energy equivalent of different types of dwelling units

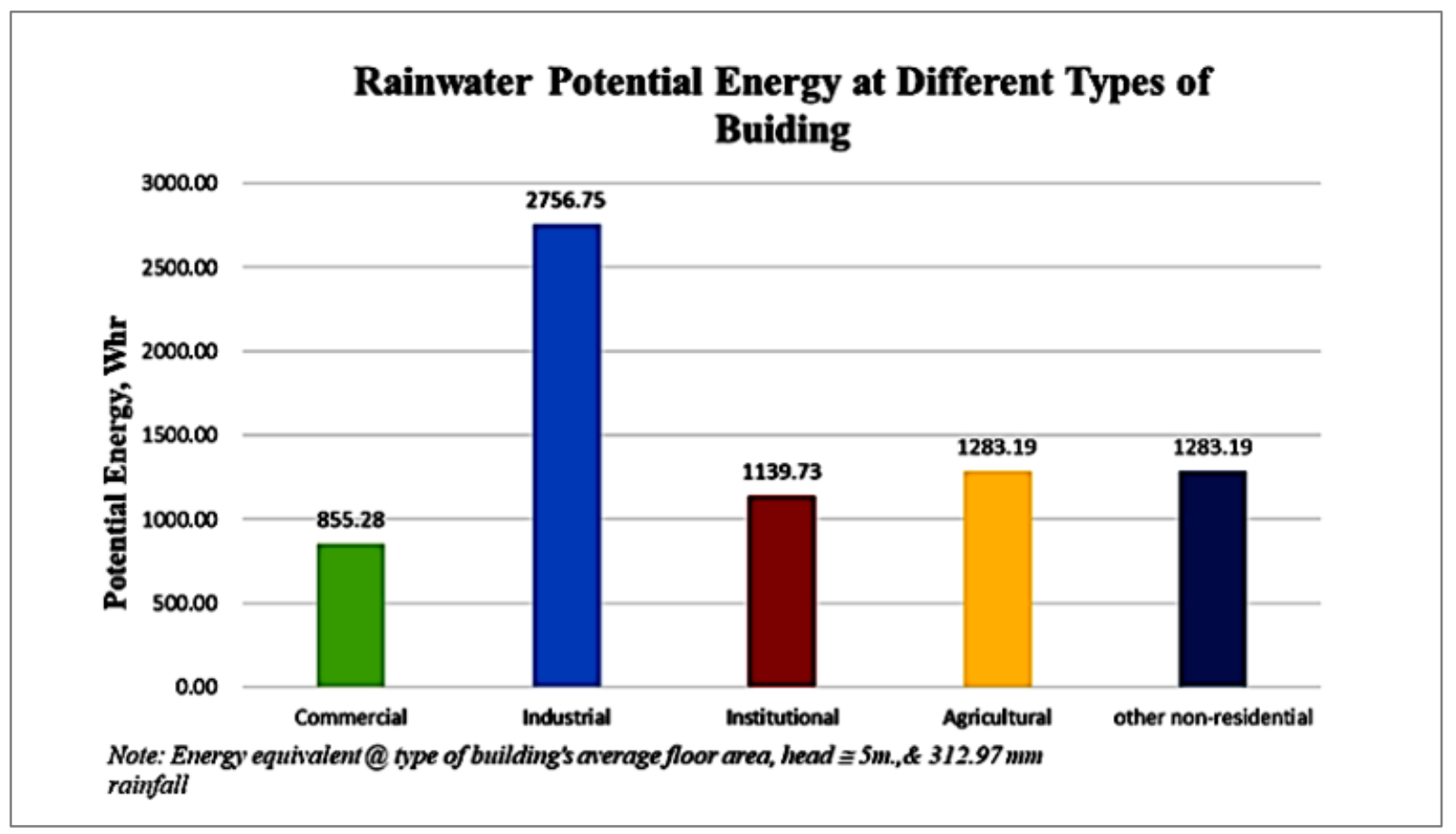

Figure 4. Potential energy equivalent of different types of building 


\subsection{Rainfall Precipitation and Building Construction Density in the Philippines}

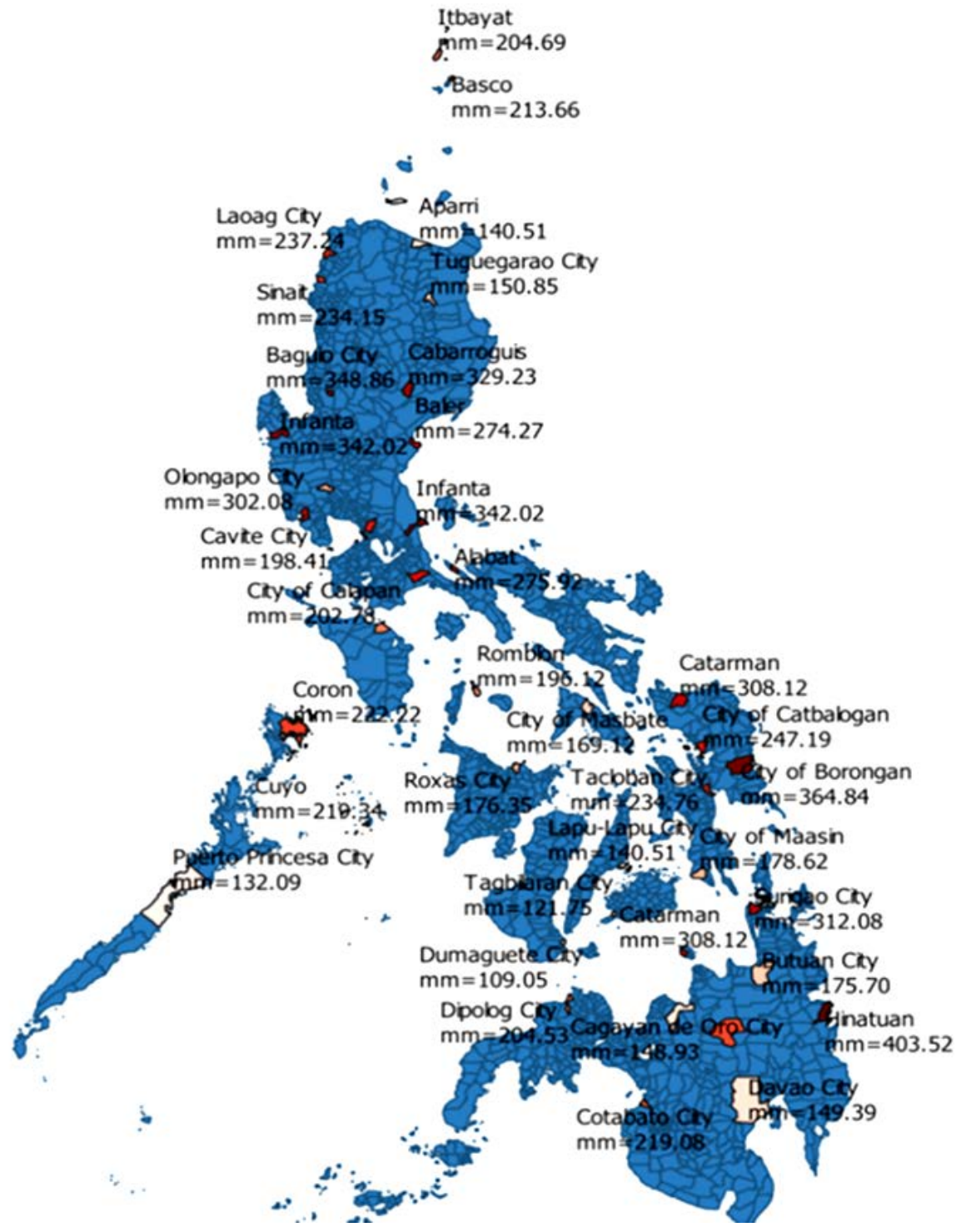

Figure 5. Average rainfall precipitation in the Philippines 


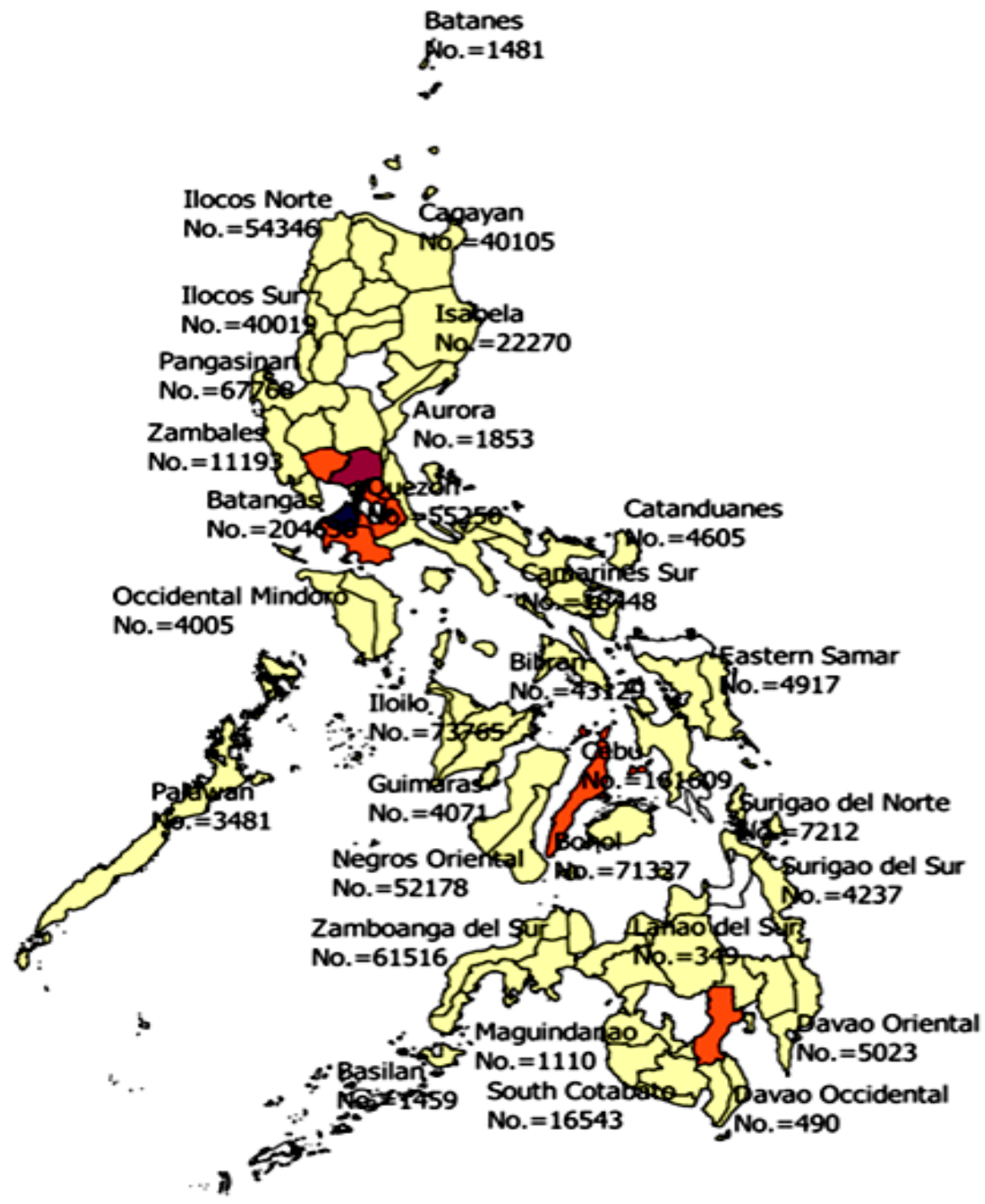

Figure 6. Location map of building construction density for residential

The location map of the study shows the geographical location in the Philippines that identifies the rainfall and building construction density of 58 stations. Figures 5 shows the average rainfall precipitation from the monthly precipitation recorded starting year 1990 to 2012 with the corresponding local name of places. Figures 6 and 7 shows the location map of the 58 stations with its number of additional approved building construction of residential buildings and commercial buildings as of first quarter of 2017. 


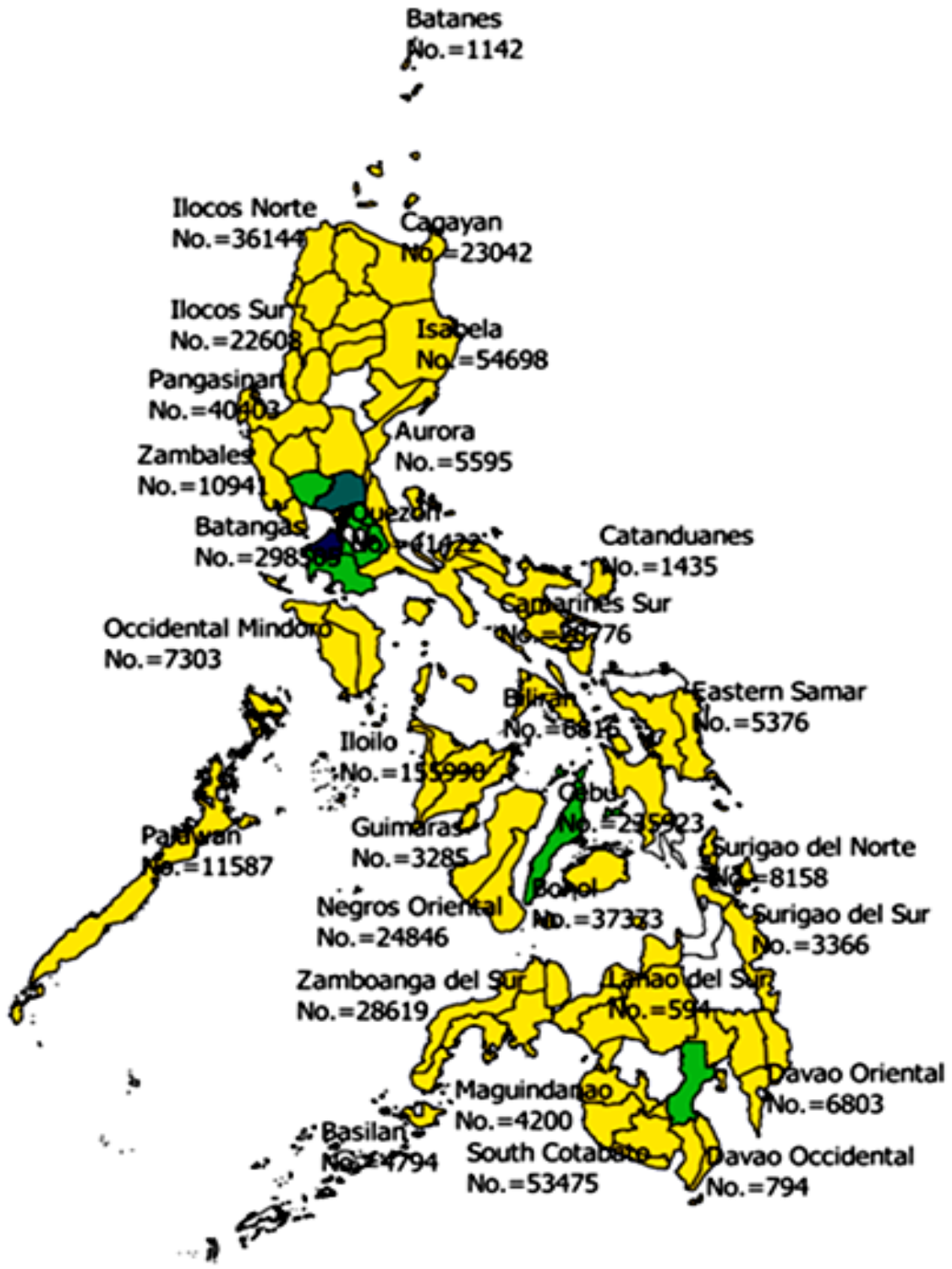

Figure 7. Location map of building construction density for commercial

\subsection{Accumulated Rainwater Energy for High Rise Building}

The Figure 8 illustrates the rainwater energy accumulated as the height of the building increases. It illustrates how energy is accumulated when the rainwater is utilized as building height increases. In this figure, the considered rainfall precipitation was from the area of Hinatuan City, Surigao del Sur and a three (3) meter height per storey building was assumed while taking the catchment area as variable. The accumulated energy measured per catchment area was measured as watt-hour per square meter $\left(\mathrm{m}^{2}\right)$ or $\mathrm{Whr} / \mathrm{m}^{2}$. 


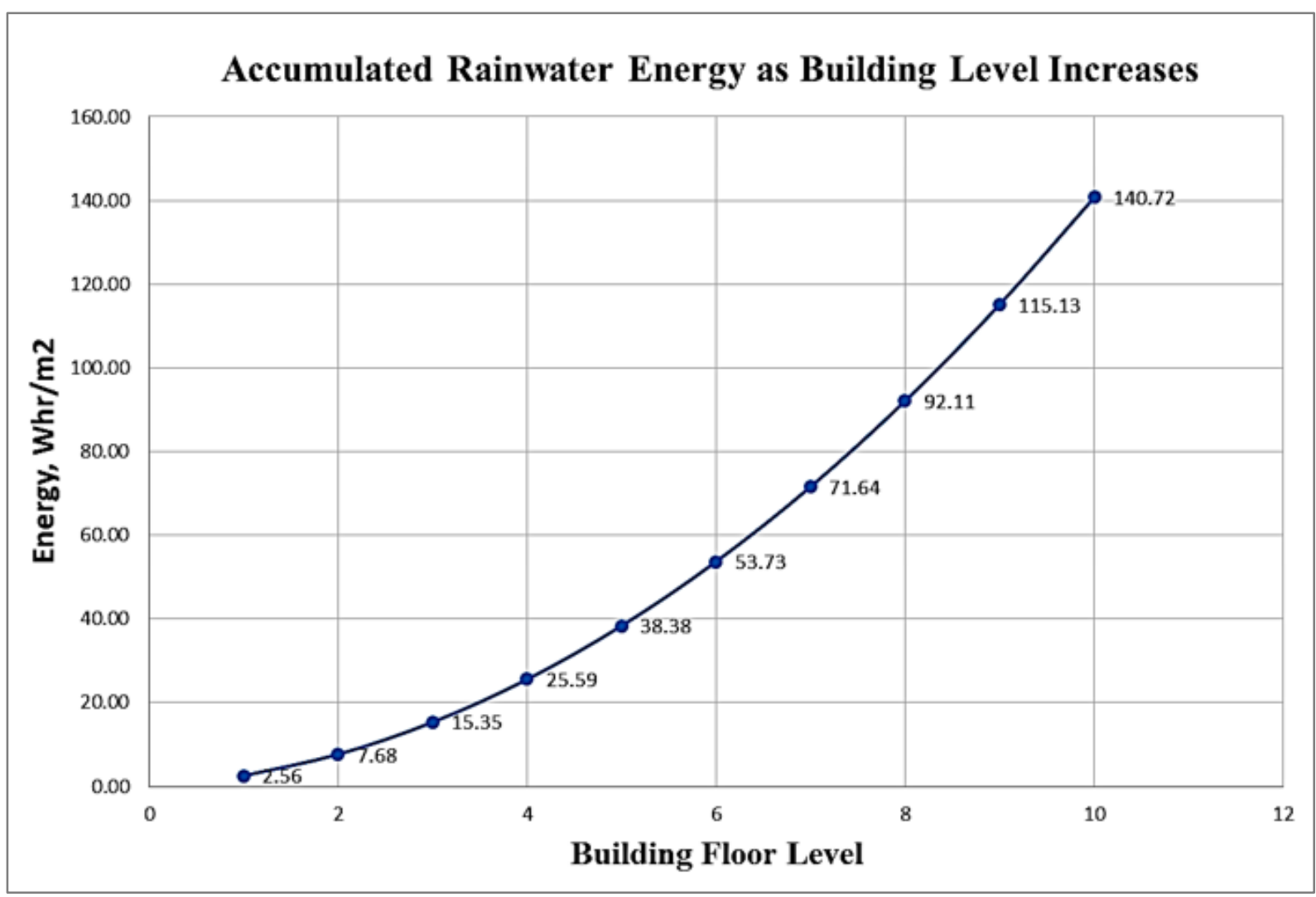

Figure 8. Accumulated energy equivalent of building

Table 4. Accumulated rainwater energy equivalent as Building Height increases

\begin{tabular}{|c|c|c|c|}
\hline Level Number & Energy, $\mathrm{X}_{\mathrm{n}}\left(\mathrm{Whr} / \mathrm{m}^{2}\right)$ & $\begin{array}{c}\text { Difference, } \\
\mathrm{D}_{\mathrm{n}}=\left(\mathrm{X}_{\mathrm{n}}-\mathrm{X}_{\mathrm{n}-1}\right)\end{array}$ & Equivalent Equation \\
\hline 1 & $\mathrm{X}_{1}=2.56$ & $\mathrm{D}_{1}=2.56$ & $\mathrm{D}_{1}$ \\
\hline 2 & $\mathrm{X}_{2}=7.68$ & $\mathrm{D}_{2}=5.12$ & $\mathrm{D}_{2}=\mathrm{D}_{1}+\mathrm{D}_{1}$ \\
\hline 3 & $\mathrm{X}_{3}=15.35$ & $\mathrm{D}_{3}=7.67$ & $\mathrm{D}_{4}=\mathrm{D}_{3}+\mathrm{D}_{1}$ \\
\hline 4 & $\mathrm{X}_{4}=25.59$ & $\mathrm{D}_{4}=10.23$ & $\mathrm{D}_{5}=\mathrm{D}_{4}+\mathrm{D}_{1}$ \\
\hline 5 & $\mathrm{X}_{5}=38.38$ & $\mathrm{D}_{5}=12.80$ & $\mathrm{D}_{6}=\mathrm{D}_{5}+\mathrm{D}_{1}$ \\
\hline 6 & $\mathrm{X}_{6}=53.73$ & $\mathrm{D}_{6}=15.35$ & $\mathrm{D}_{7}=\mathrm{D}_{6}+\mathrm{D}_{1}$ \\
\hline 7 & $\mathrm{X}_{7}=71.64$ & $\mathrm{D}_{7}=17.91$ & $\mathrm{D}_{8}=\mathrm{D}_{7}+\mathrm{D}_{1}$ \\
\hline 8 & $\mathrm{X}_{8}=92.11$ & $\mathrm{D}_{8}=20.47$ & $\mathrm{D}_{9}=\mathrm{D}_{8}+\mathrm{D}_{1}$ \\
\hline 9 & $\mathrm{X}_{9}=115.13$ & $\mathrm{D}_{9}=23.02$ & $\mathrm{D}_{10}=\mathrm{D}_{9}+\mathrm{D}_{1}$ \\
\hline
\end{tabular}

Values from Figure 8 was then tabulated in Table 4. It is the result of the factors in computing the accumulated energy as rainwater is utilized. These were the accumulated rainwater energy at every floor level $(\mathrm{X})$, the difference (D), of each succeeding building floor and the equivalent equation of each building level in terms of $\mathrm{D}$.

Values in Table 4 were used to derive the standard computation and formulate an equation to calculate the accumulated rainwater energy as the building construction height.

For level 1 (ground floor of the building), the accumulated energy will be,

$$
\mathrm{X}_{1}=\mathrm{D}_{1}
$$

For level 2, the accumulated energy will be,

$$
\mathrm{X}_{2}=\mathrm{D}_{1}+\mathrm{D}_{2}
$$

Where,

$$
\mathrm{D}_{2}=2 \mathrm{D}_{2}
$$

and

$$
2 \mathrm{D}_{1}=2 \mathrm{X}_{1}
$$

Substituting equations (6) and (3) to (4), $\mathrm{X}_{2}$ will be, 


$$
\mathrm{X}_{2}=\mathrm{X}_{1}+2 \mathrm{X}_{1}
$$

Performing the same above method to derive $\mathrm{X}_{3}, \mathrm{X}_{4} \ldots$ and to $X_{n}$. $X_{3}$ and $X_{4}$ will be,

$$
\begin{aligned}
& X_{3}=X_{2}+3 X_{1} \\
& X_{4}=X_{3}+4 X_{1}
\end{aligned}
$$

Then the standard formula for the accumulated rain energy as the building level height increases will be,

$$
\mathrm{X}_{\mathrm{n}}=\mathrm{X}_{\mathrm{n}-1}+\mathrm{n} \mathrm{X}_{1}
$$

Where $X$ is the accumulated energy in $\mathrm{Whr} / \mathrm{m}^{2}$ at a certain floor level, $n$ is the floor level number while $n=1$ for ground floor or level 1 .

\section{Conclusions}

The increasing demand on energy consumption could not be answered by creating a new energy resources, but by introducing efficient appliances and devices and or through utilization of existing and available resources. Small-scale and unutilized water resources such as rainwater could be a source for energy generation. Rainwater becomes waste and down the drains causing flood especially in urban areas and during rainy seasons. The availability of rainwater and the continuous consumption of water was a simple source of energy which can address the increasing demand of energy which could supply power for efficient devices introduced nowadays. Rainwater harvesting and water consumption per person and the increasing construction of high-rise buildings due to the increase in population could accumulate energy generation - an energy source. This idea is for an independent and on-site energy generation both for urban and rural area application. The equivalent energy generation of rainwater harvesting is categorized as a small-scale energy source.

The following was the energy equivalent of utilizing rainwater harvesting at an initial water head (height of the building) of 5 meters, average floor area of buildings and rainfall precipitation (RPC) of $312.97 \mathrm{~mm}$ in the Philippine settings; $448.81 \mathrm{Whr}$ up to $1,279.26 \mathrm{Whr}$ for residential buildings, $855.28 \mathrm{Whr}$ for commercial buildings, 2,756.75 for industrial buildings, 1,139.73 Whr for institutional buildings, 1,283.19 Whr for agricultural buildings and 1,283.19 Whr for other than non-residential buildings. The high energy equivalent of utilizing rainwater were at the locations where building constructions and rainfall precipitation considered as dense.

The study further formulate an energy equivalent of utilizing rainwater harvesting which could accumulate with an equation $\mathrm{Xn}=\mathrm{Xn}-1+\mathrm{n} \mathrm{X} 1$. Where $\mathrm{X}$ is the energy equivalent in terms of $\mathrm{Whr}, \mathrm{n}$ is the total number of floors (stories) of the building and $\mathrm{X}_{1}$ is the energy equivalent accumulated in the level 1 (ground floor) of the building.

\section{Acknowledgements}

This research would like to acknowledge the Department of Science and Technology (DOST) Engineering Research Development and Technology (ERDT), the University of San Carlos, Cebu City, Philippines and the sending institution Western Philippines University, Palawan, Philippines. An acknowledgement also to the Philippine Atmospheric, Geophysical and Astronomical Services Administration (PAGASA) and the available and accessible data from the Philippine Statistic Administration (PSA) website during the time of data gathering.

\section{REFERENCES}

[1] H. Gloria et al. Contribution of Solar Energy for Sustainable Urban Development in Ruwanda. Civil Engineering and Architecture, 7(6) pp. 271-277, 2019. DOI. 10.13189/cea.2 019.070601

[2] C. Tong et al. Performance assessment of a hybrid solar-wind-rain eco-roof system for buildings, Energy and Buildings, 127, 1028-1042, 2016

[3] J.F. Andres, M.E. Loretero. Performance of Tesla Turbine using Open Water Flow. International Journal of Engineering Research and Technology, 12(12), pp. 2191-2199 (2019).

[4] C. Matos Silva et al. Evaluation of rainwater harvesting in Portugal: Application to single-family residences. Resources, Conservation and Recycling, 94, 21-34, 2015

[5] P.S. Pudyastuti et al. Small-Scale Integrated Sustainable Roof Design (Case study in Surakarta City). Civil Engineering and Architecture. 8(4) pp. 500-506, 2020. DOI. 10.1319/cea2020.080413

[6] W.T. Chong. Techno-economic analysis of a wind-solar hybrid renewable energy system with rainwater collection feature for urban high-rise application, Applied Energy, 88 4067-4077, 2011

[7] Philippine Statistics Administration. Date Accessed: April 09, 2018

[8] J.F. Andres, M.E. Loretero. Simplified Method of Discharge Measurement for Micro-Hydropower Capacity Assessment: A Case Study for a Small-Scale Agricultural Irrigation Canal. Natural Resources and Conservation 8(2): 24-32, 2020. DOI: 10.13189/nrc.2020.080202.

[9] S. Musayeva et al. A global performance assessment of rainwater harvesting under climate change. Resources, Conservation \& Recycling 132, 62-70, 2018

[10] H. Berwanger et al. Investment feasibility analysis of rainwater harvesting in the city of Itapiranga, Brazil. International Journal of Sustainable Human Development, 
2(3), 104-114, 2014

[11] A.S. Silva, E. Ghisi. Uncertainty analysis of daily potable water demand on the performance evaluation of rainwater harvesting systems in residential buildings. Journal of Environmental Management 180 (2016) 82-93, 2016.

[12] Silva et al. Uncertainty analysis of daily potable water demand on the performance evaluation of rainwater harvesting systems in residential buildings. Journal of Environmental Management 180 (2016) 82-93, 2016.
[13] A. Stec et al. Analysing the financial efficiency of use of water and energy saving systems in single-family homes. Journal of Cleaner Production 151 (2017) 193-205, 2017.

[14] C.W.Tong et al. Performance assessment of a hybrid solar-wind-rain eco-roof-system for buildings. Energy and Buidings 127, pp. 1028-1042, 2016.

[15] C.K. Upshaw et al. Modeling electric load and water consumption inputs from an integrated thermal energy and rainwater storage system for residential buildings in Texas. Applied Energy 186, pp. 492-508, 2017. 